\title{
A Primary Study on the Recording Method of Interior Decoration in Qing Dynasty ---A Case Study of Interior Decoration of Jingfu Palace
}

\author{
RONG Xing ${ }^{\mathrm{a}}$, HE Beijie ${ }^{\mathrm{b} *}$, ZHUANG Lixin $^{\mathrm{c}}$ \\ ${ }^{a}$ School of Architecture, Tianjin University, the Wei Jin Road No. 92, Tianjin, China - rongxing1026@126.com \\ ${ }^{\mathrm{b}}$ School of Architecture, Tianjin University, the Wei Jin Road No. 92, Tianjin, China - hebeijie@126.com \\ c Department of architecture, the Forbidden City Museum, Jingshan Hill Street No. 4, Beijing, China - 1x_zhuang@163.com \\ Commission II, WG II/2
}

KEY WORDS: Qing Dynasty, interior decoration, recording methods, Jingfu Palace

\begin{abstract}
:
The existing interior decoration of Qing Dynasty is the master of that of each dynasty, with its diversified forms and complicated functions. As early as 1920s, the Rehabilitation Committee of Qing court recorded the interior furnishing in the Forbidden City by using Chinese traditional documentary method. Today, along with the constantly updated techniques, the recording method for the current situation of interior decoration has gradually developed from two-dimensional drawings into digital and comprehensive record. However, the current research results are mostly limited to a single field. This paper takes the digital record and reproduction about the current situation of interior decoration in Jingfu Palace in the Forbidden City as an example. Through the use of photogrammetry, 3D laser scanning, virtual display and other technology and equipment at the forefront of architectural field, it makes qualitative and quantitative record about the interior decoration inside Jingfu Palace. By combing with the interpretation of historical documents, it restores the original design ideas hidden behind the current situation of interior decoration, so as to summarize the best recording and reproducing method of interior decoration of Qing Dynasty.
\end{abstract}

* Corresponding author, This paper is supported by National Natrual Science Foundation of China:(project NO, 51508377) 


\section{THE REVIEW OF RECORDING METHOD FOR THE INTERIOR DECORATION OF THE ROYAL ARCHITECTURE IN QING DYNASTY}

\subsection{The Recording Method in the Qing Dynasty}

"Yangshi Lei" as an architectural family who was in charge of royal architectural engineering in the Qing dynasty is famous in the world. When they designed the interior decoration, they preferred to investigate the original interior decoration and draw reconnaissance plan or façade to collect enough design material. (1) Of these, the reconnaissance plan is the majority, which uses the refined legend represents the separation of the interior decoration with dimensions of the separation recorded beside it. (Table 1) At the same time, survey staff records dimensions of the separation in the form of written records. The document of this kind record is named dimension Luejie(略節). (Figure 1)

\begin{tabular}{|c|c|c|c|c|}
\hline \multicolumn{2}{|c|}{ Legend } & Content & Source & Original \\
\hline 0 & 0 & \multirow{2}{*}{ Feizhao } & $005-004$ & \multirow{2}{*}{ 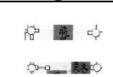 } \\
\hline $\mathrm{O}=0$ & $=0$ & & 005-004 & \\
\hline $\mathrm{O}$ & $\Longrightarrow 0$ & \multirow{2}{*}{ Langanzhao } & $008-016$ & \multirow{2}{*}{$\infty-\infty$} \\
\hline $\mathrm{O}=0$ & $=0$ & & $005-004$ & \\
\hline $\mathrm{O}=$ & $=0$ & \multirow{3}{*}{ Bishachu } & $005-004$ & 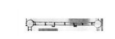 \\
\hline $0=$ & $=0$ & & $008-016$ & 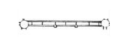 \\
\hline $0=$ & $=0$ & & 008-018 & 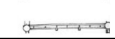 \\
\hline
\end{tabular}

Table 1. The part of interior decoration legend of Shendetang
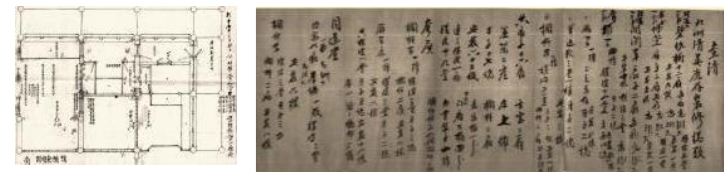

Figure 1. Reconnaissance plan and dimension Luejie of Shendetang

What's more, the official of Ministry of Internal Order writes furnishings' list, when checking furnishings throughout the palace. There are about 10,000 volumes of furnishings' list in China. Since furnishings do not change greatly each year, the official just need to sign the change of the furnishings in one copy. (Figure 2)

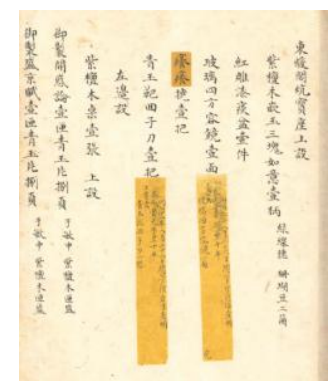

Figure 2. Furnishings' list of Dongnuange

The Yangshi Lei reconnaissance plan uses the refined legend to record form information of interior decoration, and uses dimension Luejie to record dimension information accurately. This kind of record can guarantee that the designer will receive enough design materials and ensure that other staff agree on the

(1) After preliminary statistics, the number of Yangshi Lei inerior decoration archives is about 3600, mainly in the Domestic Chinese National Library, the National Palace Museum, the First Historical Archives of China, Tsinghua University and so on. content of the record. Although furnishings' list includes only three kinds of information: location, type and quantity. But that is enough to satisfy the officials' need to manage the items in their area.

\subsection{The Recording Method Before the 21th Century}

\subsubsection{Image Record}

Since the late Qing Dynasty, with the decline of China's national power, the western colonists inspected the old buildings in China at the same time as the cultural output. Many research works are photo based catalogues or travel photography albums. (Wen, 2006) The famous research scholars are Emmanuel Chavannes (1865-1918), Ernst Boerschmann (1873-1949), Marc Aurel Stein (1862-1943), Paul Pelliot (1878-1945), Henry Kikkam Murphy (1877-1954), Osvald Siren (1879-1966) and etc. (Table 2) They conducted field surveys of the old buildings in China from Chinese culture, religion and other aspects, and retained a large amount of image data. Among them, Siren's photos involve the interior decoration of the royal architecture. Published in 1926, "The Forbidden City of Peking "includes a total of 14 pieces of architectural drawings and 274 pieces of photographs. These pieces record the spatial layout, architecture, and detailing of the royal architecture, such as the Forbidden City, Jingshan Hill, Beihai and etc. The photographs are mainly based on the architectural form and space combination sequence, but in the records of Taihe palace and the Hall of Raising Silkworms, Siren began to pay attention to the construction of the interior decoration of Chinese traditional architecture. (Figure 3)

\begin{tabular}{|c|c|c|c|}
\hline Name & Time & Place & Work \\
\hline Chavannes & $\begin{array}{l}1891- \\
1908\end{array}$ & $\begin{array}{c}\text { Northeast } \\
\text { China, Hebei } \\
\text { Province, } \\
\text { Shandong } \\
\text { Province, Shanxi } \\
\text { Province, etc. }\end{array}$ & $\begin{array}{c}\text { Mission archeol } \\
\text { ogique en Chine } \\
\text { septentrionale } \\
\text { (1909), } \\
\text { Le T'ai Chan.Es } \\
\text { sai de Monogra } \\
\text { phie d'un culte } \\
\text { Chinois (1910), } \\
\text { etc. }\end{array}$ \\
\hline Boerschmann & $\begin{array}{l}1906- \\
1909\end{array}$ & $\begin{array}{c}\text { Beijing, } \\
\text { Shandong } \\
\text { Province, Shanxi } \\
\text { Province, etc. }\end{array}$ & $\begin{array}{c}\text { Die Baukunst un } \\
\text { d religiöse Kultu } \\
\text { r der Chinesen } \\
\text { (1911), } \\
\text { Architecture and } \\
\text { Landscape of } \\
\text { China (1923), } \\
\text { Chinese } \\
\text { Baukeramik } \\
\text { (1927), etc. }\end{array}$ \\
\hline Stein & 1908 & Gansu Province & $\begin{array}{c}\text { Detailed Report } \\
\text { of Explorations } \\
\text { in Central Asia, } \\
\text { Kansu and } \\
\text { Eastern Iran } \\
\text { (1928) }\end{array}$ \\
\hline Pelliot & 1908 & $\begin{array}{l}\text { Mo Kao Grotto } \\
\text { at Dunhuang }\end{array}$ & $\begin{array}{c}\text { Grottes de } \\
\text { Touen-Houang } \\
\text { (1921) }\end{array}$ \\
\hline Siren & 1921 & Beijing & $\begin{array}{l}\text { The Walls and } \\
\text { Gates of Peking } \\
\text { (1924), The } \\
\text { Forbidden City } \\
\text { of Peking (1926) }\end{array}$ \\
\hline
\end{tabular}

Table 2. The part of western scholars investigated China in the early 20 th Century 

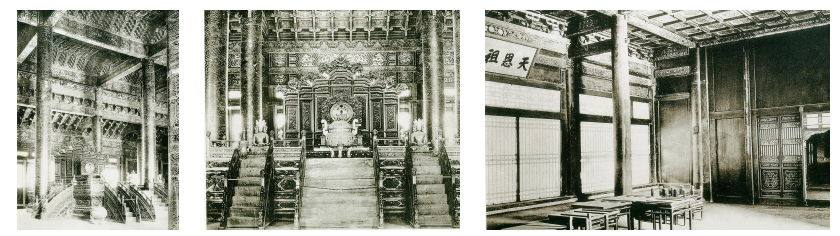

Figure 3. Interior space photos shot by Siren

Before and after 20th Century, Japanese scholars took the decoration of Chinese traditional architecture as the focus of the investigation, and took many photos of interior decoration. (Xu, 1999) For example, "The Imperial City of Peking China "(1906) published a total of 172 photos, including 34 pieces of interior decoration photos. From the recorded content, photos focus on the result of interior space, but a few photos have begun to focus on the interior decoration and its motif decoration. (Figure 4)
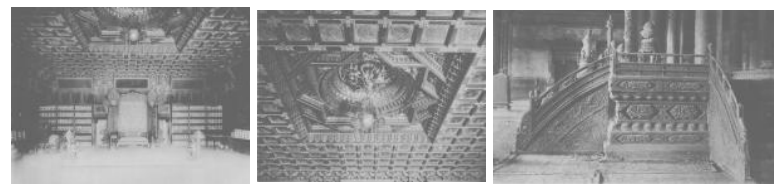

Figure 4. Interior space and interior decoration photos shot by Ogawa Kazuma

\subsubsection{Image and Text Record}

In the 1930s, Japanese scholar Sekino Tadashi surveyed important buildings in the investigation of Mountain Resort. Due to the lack of staff and limited time, he just added the documentary description of the interior decoration on the basis of the image record. For example, when describing the throne of the Hall of Danbojingcheng, "Rehe - album and interpretation" described that “屋內中央設以高出地面壹段的寶座。此寶座 的材料皆為紫檀，其前面與左、右兩側有木階，高欄上鑲 有黄楊木透雕裝飾板，手法精美、端麗，十分雅致。”In addition to recording the general appearance of the throne, the characters also recorded the basic information of the wood species.

Because of the lack of certain professional knowledge, foreigners can only use simple characters to record the interior decoration. Compared with them, Chinese historians who have deep erudite through paternal teaching and influence can describe interior decoration more detailed. Mr. Zhu Jiajin, for example, has such a description in the article "the mansion of monarch of Boduolegetai”: “正房及耳房都用“金磚”墁地, 有地下暖道, 用楠木雕萬蝠紋碧紗櫥隔斷前後間, 上有仙 樓可登。耳房內樟木板壁鑲紅木框，黄楊木的横椐及隔扇 窗上飾冰梅紋嵌紫檀卡子花。建筑的外貌有殿宇的氣派,

內檐裝修又是最講究的居室。” (Zhu, 2009) The article not only records the types of interior decoration, but also emphasizes the details of the interior decoration materials and decorative motifs.

\subsubsection{Image, Text and Survey Drawing Record}

When foreign scholars surveyed Chinese architecture on a large scale, the Institute for Research in Chinese Architecture began to use western surveying and mapping methods to survey Chinese traditional architecture. Scholars focused on records of wooden structure, for the measurement of interior decoration, only control dimension record was adopted. For example, in 1935 when surveying Wenyuange, Liang Sicheng and other scholars recorded types and control dimensions of interior decoration clearly. (Figure 5) At the same time, by digging through literature value of "Practice of the Qing Dynasty engineering project", the text record of interior decoration became more abundant. (Liu, 1935) After the founding of the people's Republic of China, with the development of various colleges and universities to carry out the teaching of ancient architecture survey, the interior decoration records have gradually improved. Among them, Tianjin University uses the expression form of watercolor rendering to record the colour information of interior decoration. (Figure 6)

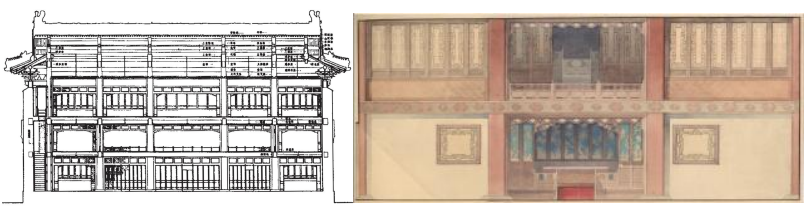

Figure 5. (Left) Survey drawing of Wenyuange Figure 6. (Right) Survey drawing of Juanqinzhai

In the last forty years, the scholars have been using the combination of three methods of image, text and survey drawings to record the interior decoration. "The Palace Decoration of the Forbidden City" ( 1995) is the concentrated expression of this method. Take Bishachu of Taijidian as an example, the contents are based on photo records, with survey drawings, together with a summary of written records to reproduce the Forbidden City interior decoration. (Figure 7) (Department of Architecture, 1995)
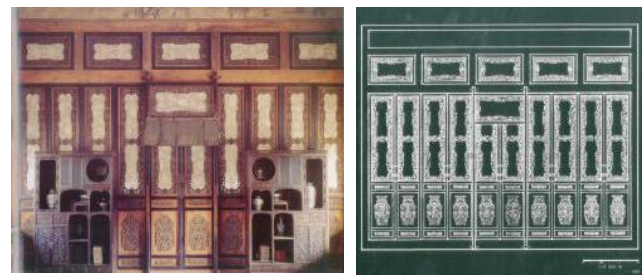

Figure 7. Photo and survey drawing of Taijidian

\subsubsection{Preliminary Summary}

To summarize recording method before the 21th century, the method develops from one single image method to three methods of combining image, text and survey drawing. In the process, text record also evolves from a single form record to a variety of forms, materials, structures, and so on. The survey drawing also develops from the control dimension record to multi-level record with the detail dimension, decoration motif and so on.

\subsection{The Recording Method of the 21st Century}

1.3.1 Three Dimensional Information Acquisition and Digital Survey Drawing Record

In the 1990s, three dimensional laser scanning and photogrammetry have been applied to the records of ancient architecture. The $21 \mathrm{st}$ century, considering the threedimensional information collection can not contact with cultural relics, can be collected positive photographic images and other advantages, interior decoration information collection began to refer to this method. At the same time, due to the high precision of digital drawings, digital survey information easy to edit and other advantages, when the Tianjin University surveyed the Summer Palace in 2005, Tianjin University research team used the method of computer graphics to focus on recording interior decoration, not only in the section on the detailed drawing, while painting the pattern of a single separator. (Figure 8) In the subsequent restoration of the Fuwangge, scholars added different patterns which means different damages to the digitized drawings to record the damaged condition. (The Forbidden City Museum, 2014) 


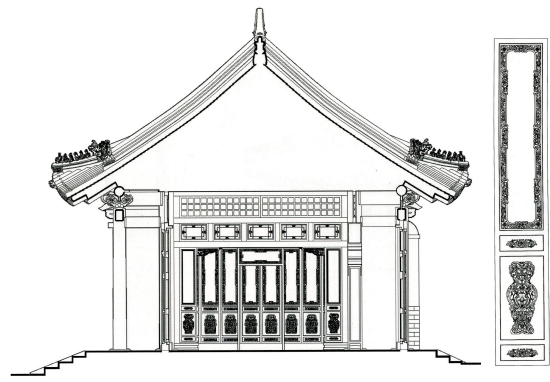

Figure 8. Survey drawings of Yunjindian

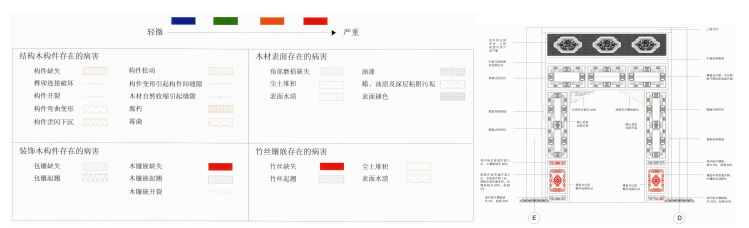

Figure 9. Damages record of Fuwangge's Luodizhao

1.3.2 The Image, Text and Digital Record of Production Process

In order to ensure the superb production process of interior decoration to continue, as early as the middle of the last century, Mr. Wang Shixiang explored and collected artisan regulations of interior decoration in the Qing Dynasty, and in 2008 published a book named "The Collection of artisan regulations of interior decoration in the Qing Dynasty". (Wang, 2008) Subsequently, scholars from all walks of life under the influence of "Taking the craftsman as a teacher" prefer to visit craftsmen, with intuitive image collection recording methods to retain the traditional process.In recent years, for the recording space combination of complex mortise and tenon structure, the researchers introduced the method of three-dimensional digital modeling, and made a clear record of the process of tenon and mortise joint by using the reappearance form of spatial perspective. (Figure10)

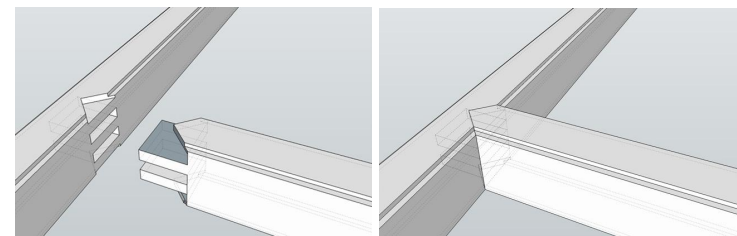

Figure 10. Straight tenon and mortise structure model

1.3.3 Microscopic Identification Record of Materials When studying the restoration of interior decoration, the material identification can not be avoided. At present, scholars mainly use microscopic identification method to record detail information about materials. The cell sections of the decorated samples were observed under a microscope and compared with the existing tree sections. (Cao, 2015) The type of wood used for the interior decoration could be determined.Through the observation of the paint layer materials, paint layers, stacking relationship information, and then record decoration process of painting and the history of the renewal times. (Figure 11) (The Forbidden City Museum, 2014)

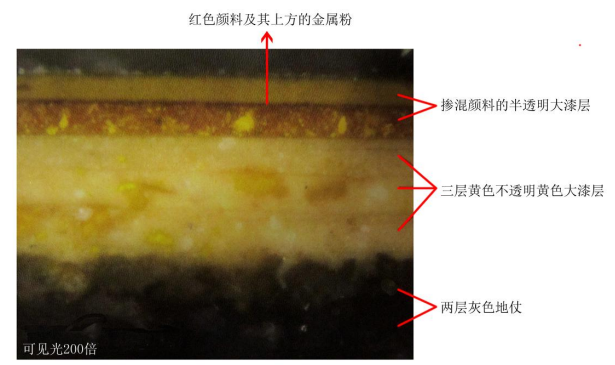

Figure 11. Microscopic image of paint layers of Fuwangge

1.3.4 Information Integration Record

For the full integration of interior decoration information, in the study of Fuwangge protection, researchers tried to use the Building Information Model (BIM) technology to record internal decoration. The technology is based on model library, with the in-depth investigation record, researchers can gradually add various kinds of information to interior decoration, and then form a perfect information record index library for interior decoration.Although this recording method is in the exploration stage, its innovative introduction provides the possibility for the informatization of the interior decoration status record.

\subsubsection{Preliminary Summary}

To summarize recording methods of the 21th century, the first is to complete the interior decoration digital drawing record. After that, with the deepening of interior decoration research, the information needed to be collected are more varied, and new recording methods are introduced accordingly. In the end, the information of interior decoration are recorded and integrated by BIM technology to complete the informatization record of interior decoration.

\section{RECORDING METHOD FOR THE INTERIOR DECORATION OF THE JINGFU PALACE}

In May 2015, the school of architecture of Tianjin University was commissioned by the Forbidden City museum to conduct a comprehensive survey of the Jingfu Palace, focusing on the fine surveying of interior decoration. We have adopted a variety of recording methods to record the space size, shape, structure, historical documents and other information of the interior decoration of Jingfu Palace, in order to provide detailed basic data for future research.

\subsection{Dimension Record}

This survey mainly adopts the method of manual measurement, complete the dimension of Jingfu Palace's interior decoration. In order to speed up the process of record and dimension acquisition, besides the traditional method of marking the data on the manuscript, the author also designs the dimension acquisition form. The form takes the dimension of the inner mouth as the reference object, records the dimension of the nodes inside each mouth, and makes the connection of the datum dimension of each inner mouth, so as to ensure the integrity of the data measurement. (Figure 12) Then use statistical method to list the specific components of each partition, and draw the detailed drawings of interior decoration with the method of computer graphics. 


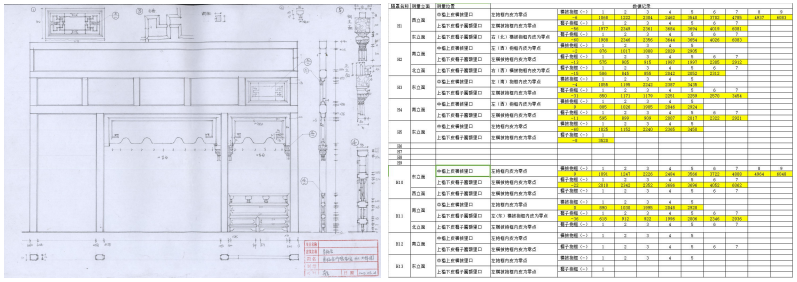

Figure 12. Dimension record of Jingfu Palace

\subsection{Form Record}

There are 13 pieces of interior decoration partitions in jingfu palace, including 1 piece of Langanzhao, 1 piece of Jituizhao, 2 pieces of Bishachu, 2 pieces of Geshankanqiangmenkou, 1 piece of glass partition, 1 piece of Fokan, 2 pieces of Menkou, 1 piece of Luodizhao, 1 piece of Kangzhao and 1 piece of wood siding wall. Decorative motif is divided into two kinds of passionflower which is only used in Fokan and longevity. To accurately record the form of interior decoration, in addition to the CAD description pattern, also use the software colouring, photo puzzle and handheld 3D laser scanning point cloud images to record. (Figure 13) The three methods complement each other, the software colouring can clearly reflect the relationship between the object and color information, but lacking details of existing circumstances. Photo puzzle can solve the software colouring's drawbacks and add texture and damage records. However, it is difficult to avoid the problem of angle perspective, so there is a certain error in dimension authenticity. Three dimensional point cloud image can guarantee the authenticity of the dimension information because it can obtain the positive image.

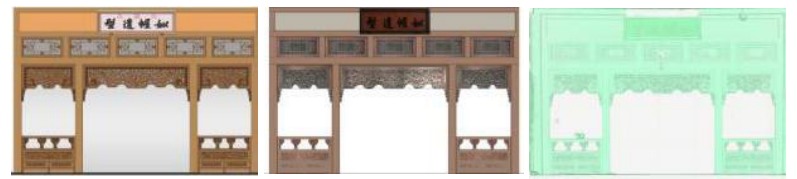

Figure 13. The Langanzhao of Jingfu Palace

\subsection{Structure Record}

The interior decoration structure of Jingfu Palace mainly includes two parts: mortise and tenon structure and cloud nail structure. Use the way of drawing sketches, photographs to record the Jingfu Palace interior decoration mortise and tenon form and dimension information, and through software modeling method to complete the the three-dimensional record of mortise and tenon structure. (Figure 14) The dimension information of the cloud nail structure is recorded by the method of drawing sketch, and the form information is recorded by extension sampling and shooting the positive photograph. (Figure 15)
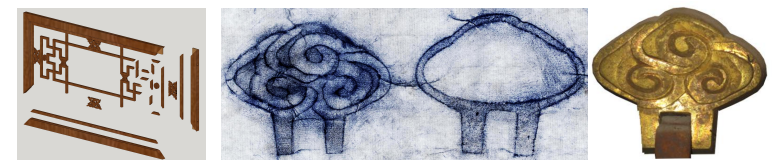

Figure 14. (Left) Mortise and tenon structure model

Figure 15. (Right) Extension sampling and positive photograph of the cloud nail

\subsection{Historical Information Record}

The existing buildings of Jingfu Palace were built in Qianlong thirty-five years (1770), modeled after Jingyixuan. In order to improve the historical information of Jingfu Palace's interior decoration, we collect and sort out Qing Dynasty documents and retained images. There are 42 directly related documents and 2 indirectly related Yangshi Lei archives. (2) By combining the recording methods of taking photos and drawing fine digital drawings, we can record the location, size and form of the historical sites of Jinfu Palace's interior decoration. (Figure 16) Take the research method of historical origin for reference, trace the historical origin of the historical site of Jinfu Palace's interior decoration. Use the table statistics form of comparison to record the possibility of historical Jingfu Palace. (Table 3)

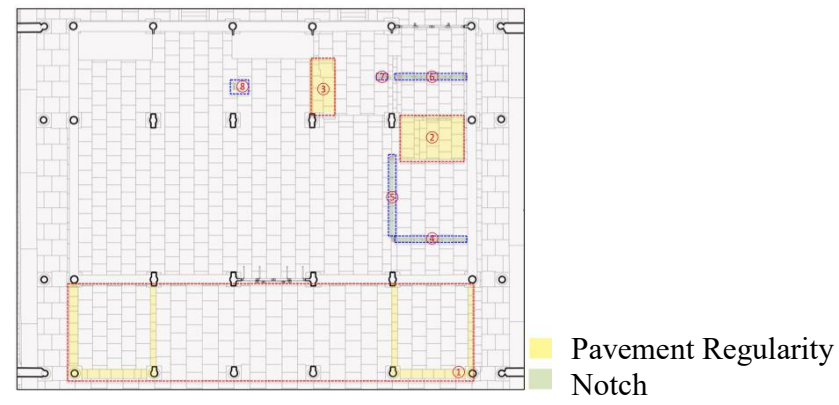

Figure 16. Historical sites of Jingfu Palace

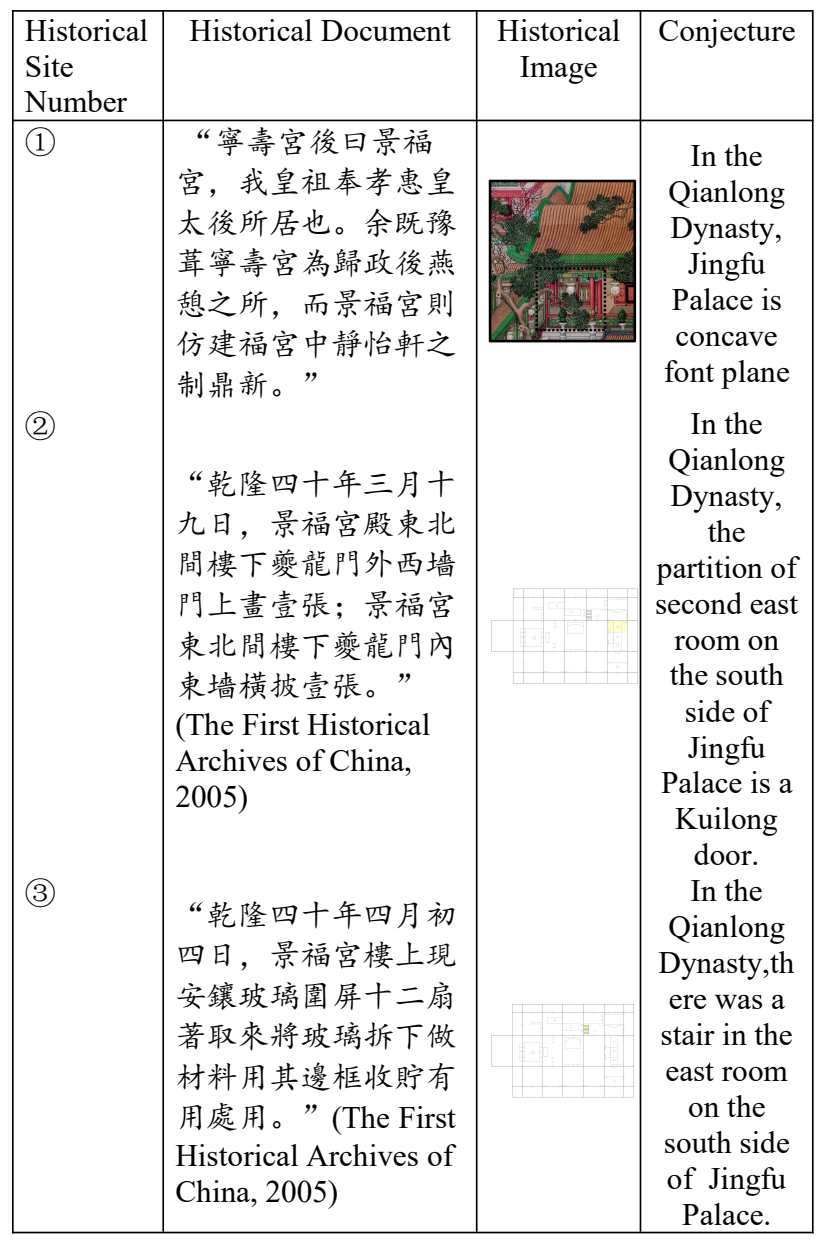

Table3. The possibility of historical Jingfu Palace

(2) Because Jingfu Palace imitates Jing Yixuan (Jing Yi Xuan imitates Hanyunzhai), so take Yangshi Lei archives of Hanyunzhai as indirect reference. 


\subsection{Information Integration Record}

At present, the BIM technology has been used to construct the inner decoration database of Jingfu Palace, and to add the space dimension and structural information of each component, and to complete the component relation of mortise and tenon structure. At the same time, we integrate damage conditions and known historical information of Jingfu Palace's interior decoration. With the renovation work in Jingfu Palace, its interior decoration BIM model can continue to improve, adding more information such as human intervention. (Figure 17)
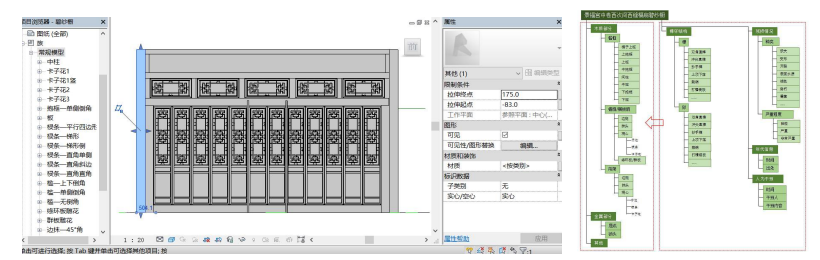

Figure 17. BIM model and ideal frame of Jingfu Palace's Bishachu

\section{SUMMARY}

For nearly a hundred years of the Qing Dynasty interior decoration's study history. With the deepening of the study, the recording methods of interior decoration in Qing Dynasty have been developed from the original single image record to the comprehensive record today. In order to integrate all aspects of interior decoration, BIM technology has also been applied to the record. Although the use of some recording methods is not yet mature, it opens a new phase for our future exploration. In this paper, the recording methods of interior decoration in Qing Dynasty are preliminarily combed, and the recording methods of interior decoration of Jingfu Palace are taken as an example. We hope to attract the attention of scholars from all walks of life and realize the qualitative and quantitative information record of interior decoration in Qing Dynasty as soon as possible.

\section{REFERENCES}

Wen Yuqing, D, 2006, The Summary Reviews of Chinese Architecture History Studies During the 20th Century, Tianjin University, pp. 23.

Xu Subin, M, 1999, Japanese Research on Chinese Cities and Architecture, China WaterPower Press, Beijing, pp. 53.

Zhu Jiajin, M, 2009, The Corpus of the Forbidden City, the Forbidden City Publishing House, Beijing, pp. 537.

Liu Dunzhen, Liang Sicheng, J, 1935, Wenyuange Survey, Society for the Study of Chinese Architecture Transaction, 6(2), pp. 54.

Department of Architecture, the Forbidden City Museum, M, 1995, The Palace Decoration of the Forbidden City, the Forbidden City Publishing House, Beijing, pp. 127.

The Forbidden City Museum, M, 2014, Qianlong Garden Research and Protection - Fuwangge, the Forbidden City Publishing House, Beijing.

Wang Shixiang, M, 2008, The Collection of artisan regulations of interior decoration in the Qing Dynasty, China Bookstore Press, Beijing.
Cao Qi, D, 2015, Study on Variations of Physical and Mechanical Properties of Ancient Wood Structure in the Imperial Palace, Beijing Forestry University, pp. 16.

The First Historical Archives of China, Art Museum The Chinese University of Hong Kong, M, 2005, Production Office Archives in the Qing Dynasty, People's Publishing House, Beijing. 